\title{
The Origins of Private Social Insurance: Public Policy and Fringe Benefits in America, 1920-1950
}

\section{Citation}

Dobbin, Frank R. 1992. The origins of private social insurance: Public policy and fringe benefits in American, 1920-1950. American Journal of Sociology 97, no. 5: 1416-1450.

\section{Published Version}

http://dx.doi.org/10.1086/229906

\section{Permanent link}

http://nrs.harvard.edu/urn-3:HUL.InstRepos:3264874

\section{Terms of Use}

This article was downloaded from Harvard University's DASH repository, and is made available under the terms and conditions applicable to Other Posted Material, as set forth at http:// nrs.harvard.edu/urn-3:HUL.InstRepos:dash.current.terms-of-use\#LAA

\section{Share Your Story}

The Harvard community has made this article openly available.

Please share how this access benefits you. Submit a story.

Accessibility 


\title{
The Origins of Private Social Insurance: Public Policy and Fringe Benefits in America, 1920-1950
}

\author{
Frank R. Dobbin \\ The American Journal of Sociology, Vol. 97, No. 5. (Mar., 1992), pp. 1416-1450.
}

Stable URL:

http://links.jstor.org/sici?sici=0002-9602\%28199203\%2997\%3A5\%3C1416\%3ATOOPSI\%3E2.0.CO\%3B2-C

The American Journal of Sociology is currently published by The University of Chicago Press.

Your use of the JSTOR archive indicates your acceptance of JSTOR's Terms and Conditions of Use, available at http://www.jstor.org/about/terms.html. JSTOR's Terms and Conditions of Use provides, in part, that unless you have obtained prior permission, you may not download an entire issue of a journal or multiple copies of articles, and you may use content in the JSTOR archive only for your personal, non-commercial use.

Please contact the publisher regarding any further use of this work. Publisher contact information may be obtained at http://www.jstor.org/journals/ucpress.html.

Each copy of any part of a JSTOR transmission must contain the same copyright notice that appears on the screen or printed page of such transmission.

JSTOR is an independent not-for-profit organization dedicated to and preserving a digital archive of scholarly journals. For more information regarding JSTOR, please contact support@jstor.org. 


\title{
The Origins of Private Social Insurance: Public Policy and Fringe Benefits in America, 1920-1950 ${ }^{1}$
}

\author{
Frank R. Dobbin \\ Princeton University
}

\begin{abstract}
How did the American system of private, employment-related pension and health insurance arise? Data on corporate fringe-benefit programs during the second quarter of the 20th century contradict the received wisdom that benefits rose in response to wartime federal policy changes and industrial factors. Instead it appears that public policies such as the Wagner Act and Social Security led to union and business support for private insurance, which in turn spurred the growth of fringe benefits. The historical record suggests that neoinstitutional and conflict approaches must be synthesized to explain the expansion of fringe benefits: institutional factors influenced organizational outcomes by affecting interest group goals.
\end{abstract}

\section{INTRODUCTION}

Over the past century the United States has developed an elaborate system of private, employment-related insurance to protect Americans against income loss due to illness and old age. Today over half of all full-time employees in the private sector are covered by employerprovided health insurance and pension benefits (Rein 1982, p. 132). In 1980 , the private sector paid for $57 \%$ of total U.S. health expenditures, an amount nearly 3.5 times greater than the average (17\%) private-sector contribution to health care costs among Western European nations. ${ }^{2}$

${ }^{1}$ I am particularly grateful to Jim Baron and Dev Jennings for helping to shape my thoughts. Thanks to Edwin Amenta, Marvin Bressler, Daniel Cornfield, Ronald Jepperson, John Meyer, Jill Quadagno, Suzanne Staggenborg, Cliff Staples, Paul Starr, Beth Stevens, and two $A J S$ reviewers for useful comments on an earlier draft. Correspondence may be directed to Frank Dobbin, Department of Sociology, Princeton University, Princeton, New Jersey 08544.

${ }^{2}$ The data on combined pension and health coverage includes only full-year nonfarm employees. The countries for which comparative data were available are Austria, Belgium, Denmark, Finland, France, Germany, Ireland, Italy, the Netherlands, Norway, Sweden, Switzerland, and the United Kingdom (Esping-Andersen 1990, p. 69).

(c) 1992 by The University of Chicago. All rights reserved.

0002-9602/92/9705-0006\$1.50 
Likewise, the private sector provided $21 \%$ of total pension benefits in the United States, more than double the average private-sector contribution (9\%) in Europe (Esping-Andersen 1990, p. 85). In an effort to understand the origins of America's system of employment-related income protections, this article examines the decline of industrial welfare work and the rise of corporate fringe-benefit programs in the second quarter of the 20th century.

\section{Forms of Employment-related Coverage}

Welfare work.-Pension and health coverage appeared along with other forms of "welfare work," such as company housing and recreational programs, in the teens and twenties in firms like General Electric, U.S. Steel, Pullman, and International Harvester. Employer-financed welfare programs were unsecured, and, because they were popularized as a means to increase worker loyalty, benefits were commonly denied to known union activists (Quadagno 1988, chap. 4). Employers paid for early "informal" pension programs from current income, and mutual benefit associations maintained contributory employee-financed funds that paid benefits to injured and ill employees and sometimes to their survivors (Brandes 1976). Such associations had been established as early as the 1860s in dangerous industries, and in the 1920s they became an integral part of company welfare work. Like informal pension schemes, most mutual benefit associations could be terminated by the employer at will. While some employers used welfare work to fend off unions, others simply saw it as a way to maintain the work force. As one Midwestern businessman put it, "When I keep a horse and I find him a clean stable and good food I am not doing anything philanthropic for my horse" (Brandes 1976, p. 31).

Health and pension insurance.-Between the twenties and the fifties, firms installed health and pension insurance plans that put coverage on a sound actuarial basis and guaranteed that benefits would be paid. Group pension insurance was financed by joint employer-employee contributions to a private insurance company program, and benefits were usually calculated on the basis of years of service. Group accident/sickness insurance guaranteed a flat daily payment for each day of work missed on account of illness or injury-typically two-thirds of normal wages (James 1947, p. 263; National Industrial Conference Board [NICB] 1934, p. 13). In many settings this early form of health coverage was later replaced or supplemented by medical and hospitalization coverage. 
Perspectives on Employment-related Coverage

Industrial arguments. - A number of analysts have linked the rise of group insurance to industrial factors. First, some trace insurance schemes to efforts to quell turnover when competition for workers heated up in the late thirties and forties-health and pension benefits based on job tenure were expected to discourage job changes (see Slichter 1961). Second, labor segmentation theorists suggest that turnover was most costly in capital-intensive, core industries that relied on firm-specific skills, and that those industries increased wages and benefits to induce long-term employment (Doeringer and Piore 1971; Hodson 1978; Edwards 1979, p. 142). In support of this view Gordon, Edwards, and Reich (1982, pp. 195-212) find sectoral wage differences as early as 1914 and argue that today's labor-market segments and associated remuneration differences had crystallized by 1950. Third, others argue that union gains after the Wagner Act stimulated the growth of fringe benefits, either because unions sought new victories in contract negotiations or because employers voluntarily adopted fringe benefits to thwart organizing efforts (Bernstein 1972; Jacoby 1985). Finally, organizational theorists have argued that growth in firm size leads to the formalization of employment relations (Blau and Schoenherr 1971; Pugh et al. 1969), and analysts indeed date the rise of formal, insured types of health and pension coverage to the war years, when firms grew dramatically in size. Arguments broadly similar to these have been made about the rise and decline of welfare work. Analysts suggest that welfare work rose in response to union activism in the twenties and declined in the early thirties when the Depression undermined union power and dampened labor turnover (Brandes 1976; Brody 1980).

Public policy arguments. - Others have tied the rise of private insurance to the broad public policy stance of the United States and to specific laws and policies. Jill Quadagno $(1984,1988)$ links the rise of private pensions to the weakness of public protections and to the persisting political power of industrialists who opposed social insurance. Paul Starr (1982) suggests that the growth of private health insurance was contingent on the failure of a series of public health insurance bills in the early forties.

More specifically it has been argued, as early as 1953 by Louise Ilse and as recently as 1988 by Jill Quadagno and by Beth Stevens, that particular wartime federal policies provided the decisive push to employment-related health and pension insurance. The wartime rise in fringe benefits is thought to be the result of the confluence of three policies: the excess-profits tax, the wage freeze, and the tax-exempt status of 
pension and health insurance payments. That is, the wartime excessprofits tax spurred firms to increase their before-tax expenditures, and increased labor turnover encouraged them to do so by raising wages. However, the wage freeze stymied them. Caught in a bind between the excess-profits tax and the wage freeze, employers gained relief in the form of federal rulings that employer payments for pension and health insurance were not covered by the wage freeze and were tax-deductible (Munts 1967; Macaulay 1959). The huge increases in health and pension insurance during the early forties are attributed by many to this set of circumstances, which purportedly caused employers to install or expand fringe-benefit packages in lieu of increasing wages.

The empirical sections below look at welfare work and insurance practices in the early years of the Depression, in the last half of the thirties, and during World War II. Industrial arguments receive little support in the data on the Depression years, because both welfare work and insurance rose during the early 1930s when all of the industrial factors associated with a tight labor market were mitigated by the economic collapse. Moreover, interindustry data from the forties suggest that industrial factors cannot explain wartime increases in insurance coverage. Public policy arguments also receive little support, because the wartime rises in health and pension benefits preceded the war-related wage freeze and excess-profits tax.

Institutional context and interest group goals. - I develop an alternative argument that draws on insights from neoinstitutional organizational theory and institutional theories of public policy, but which fills an important gap in those theories. These perspectives point to the ways in which institutional structures constrain the policy choices made by organizations and by nation-states. At the organizational level, practices and structures become institutionalized in the environment-often in response to public policy inducements - and then diffuse across all sorts of organizations (Meyer and Rowan 1978; DiMaggio and Powell 1983; Tolbert and Zucker 1983). In the process of institutionalization, practices are socially constructed as rational and enter the body of accepted corporate practice. For the most part, organizational theorists have neglected the role of interest groups in promoting salient public policies at the political level, and in helping to institutionalize certain organizational practices (Perrow 1986; DiMaggio and Powell 1991). Some notable exceptions include Fligstein's (1990) work linking federal antitrust policies to the goals of corporate managers and, in turn, to corporate strategy, and Baron, Dobbin, and Jennings's (1986) work linking wartime federal controls on labor turnover to the goals of personnel professionals and, in turn, to changing personnel practices. This study extends this line of research by examining 
how public policy shifts changed the organizational and political goals of salient interest groups, and how those altered goals in turn stimulated the growth of fringe benefits.

The new institutionalism in political science has, unfortunately, helped to validate organizational studies that neglect conflict, because as a polemic against the conflict approach to policy-making it has deemphasized interest group behavior (Krasner 1984; Zysman 1983; Skowronek 1982). Some have examined how institutions offer differential resources to different groups (Weir and Skocpol 1983), but few have examined the larger question of how institutional context shapes group goals in the first place and even determines what kinds of groups will emerge (but see Hall 1986). The evidence presented below suggests that institutional theorists should treat group behavior as an intermediate variable between institutional context and organizational and political choices. If the goals of interest groups such as unions vary considerably across time and space, and they do, then institutionalists should be examining the contextual factors that influence those goals.

In the case of fringe benefits, by tracing the effects of public policy on labor and business group preferences and on the insurance industry, we can understand why those groups pursued particular goals at particular points in time. The prevalence of fringe-benefit programs increased in the second quarter of this century largely because public policy created incentives that caused each of these groups to promote health and pension coverage in organizations. This approach highlights a central weakness in the conflict approach, namely the premise that interest groups have predictable, time-invariant goals. In fact, union and business goals switched back and forth between employer-provided insurance and social insurance as public policy changed. The approach outlined here brings the insights of institutional theory and conflict theory together.

How did public policy influence the goals of business and labor groups? First, the combination of early industrial development and late state development left the United States with a large number of industrial workers in the last quarter of the 19th century and with a state that showed no signs of being able to provide them with social insurance. To fill the gap, benevolent societies (later unions) appeared in dangerous industries such as railroads and mining; firms installed their own informal protections for workers; and a private life insurance industry arose to protect families against destitution in the event of the death of the breadwinner (Zelizer 1979). These private forms of coverage would have lasting effects. First of all, the United States developed a strong insurance industry that would promote private insurance and would lobby against public coverage. Second, American Federation of Labor (AFL) leadership came to believe that unions' benevolent functions increased member 
loyalty, thus they supported private forms of coverage until about 1932 . Then, after the passage of the Social Security Act in 1935, case law surrounding the Wagner Act caused unions to spend their energies fighting for the right to bargain over fringe benefits, which turned them into supporters of private coverage during the late thirties and forties. Third, some business leaders supported social insurance in the teens, but in the absence of public protections the business community at large became wedded to employer-provided insurance by about 1920; they too had come to believe that it helped them win worker loyalty. After the owners of some center firms supported Social Security in the midthirties, the majority of capitalists backed employer-provided benefits during the forties, as part of the fight with unions to keep fringe benefits off the bargaining table. After public policy came to favor unions in benefit negotiations, business leaders led a successful fight for the expansion of Social Security benefits in the early fifties. Public policy context, then, shaped the changing goals of these groups, and in the process it contributed to the rise of private fringe-benefit programs. Moreover, public policies frequently had unintended effects, as when Social Security legislation effected increases in the popularity of private pensions.

\section{THE DATA}

This article tries to sort out the origins of employment-related pension and health insurance by examining interindustry data that were collected by the National Industrial Conference Board (NICB) between 1928 and 1946. The data facilitate interindustry and over-time comparisons that make it possible to evaluate competing theories of the rise of insurance. The NICB is a business association that conducts studies of current business practices. It carried out extensive industrial surveys in 1928, 1935, 1939, and 1946 that included questions about informal pensions, mutual benefit associations, pension insurance, and health insurance (NICB 1929, 1936, 1940a, 1947).

The NICB's industrial relations surveys contain the best data available on the prevalence of early corporate fringe-benefit programs. Earlier studies that employed these surveys to chart the growth of personnel administration and internal labor markets have identified several advantages (Baron et al. 1986; Baron, Jennings, and Dobbin 1988). First, the surveys contain data on thousands of publicly held firms from every region of the country and every industrial sector, and they cover a crucial period of nearly 20 years. In the words of the NICB, "The Conference Board's compilation has remained the only survey of nationwide scope, embracing a wide range of practices, and presenting information in detail" (NICB 1954, p. 1). The board's 1928 survey included 6,085 firms; 
the 1935 survey included 2,452 firms with a total of 4.5 million workers, or $15.5 \%$ of the national labor force in covered industries (NICB 1936, p. 5); the 1939 survey included 2,700 firms with a total of 5 million employees (NICB 1939); and the 1946 survey covered 3,498 firms with an unreported number of employees (NICB 1947). ${ }^{3}$ Second, the surveys are comparable over time because the NICB used consistent survey techniques. It compiled a list of firms from the publications of Dun and Bradstreet, the New York Stock Exchange, and Standard and Poor, and sent surveys to all firms on the list. ${ }^{4}$ But in 1928 it was decided to extend "the study in order to develop the picture of industrial relations activities in . . . smaller establishments by oversampling firms with fewer than 250 employees" (NICB 1929, p. v). The 1928 sample includes roughly four times as many small firms as the later samples, and because there is no record of how the NICB increased the participation of small firms it is not prudent to think of the figures for small firms in 1928 as comparable with those for later years.

With the exception of the extra group of small firms in the 1928 survey, it appears that many of the same firms participated in each survey because NICB affiliates regularly took part in its studies (NICB 1954) and because the board used the same procedures to contact firms for each survey. Characteristics of the data also suggest comparability. Average firm size increased less than $1 \%$ between the 1935 and 1939 surveys, although average employment was not published in the 1946 report. Moreover the proportion of firms in each industrial category was quite stable over time, and the total number of large firms was stable over the first three waves, which suggests that many firms participated in every survey.

A third advantage is that, for the last three panels, the published reports provide data on some 25 detailed industry categories. This facilitates interindustry and over-time comparisons.

The board's reports also have several disadvantages. First, for 1928, industry-level data were reported only for small firms and only for 10 broad industry categories, thus meaningful interindustry comparisons

\footnotetext{
${ }^{3}$ While the number of firms with fewer than 250 employees was virtually the same in 1939 and 1946 (861 and 867, respectively) there is a substantial increase in the number of large firms. It is likely that more firms fitting the NICB survey profile responded in this year because there was a great deal of interest in the changes in personnel practices wrought by the war economy. Many of the NICB's regular respondents grew dramatically in size during the war, which probably explains the disproportionate increase in responses from large firms.

${ }^{4}$ E. Kay Worrell, Survey Research Center Manager at the NICB, kindly looked into the survey procedures used in the early NICB personnel studies and provided me with this information.
} 
cannot be made between 1928 and later years. ${ }^{5}$ Second, the reports certainly exaggerate the prevalence of fringe benefits in the American economy because the surveys were biased toward large publicly held firms-mean firm size was 1,836 and 1,847 employees in 1935 and 1939, respectively. Yet the board saw this size bias as an asset, for "large companies frequently are leaders in inaugurating techniques" (NICB 1954, p. 2). Likewise for the present purposes, the size bias may be seen as an asset because it highlights industry-level trends. A third disadvantage is that firms were not asked how many of their employees were eligible for benefit programs, and we know from the 1946 tables (NICB 1947) that a number of firms offered pensions only to managers. In short, while the surveys surely magnify the aggregate use of pension and health benefits in American firms, they do reflect what was going on in large firms in each sector and they have the asset of over-time comparability.

\section{THE EARLY DEPRESSION}

\section{Welfare Work}

What caused employers to install welfare practices, which served as precedents for insurance, and what caused them to abandon welfare practices and open the way for insured benefits? Unfortunately, the NICB data pick up welfare work in the middle of its life cycle, which makes sorting out causes somewhat problematic; however, industries that are outliers in the 1935 survey do provide some useful insights about industrial causes. ${ }^{6}$

The industries that show exceptionally high scores on both informal pensions and mutual benefit associations are the utilities (gas and electricity) and trade (see table 1). First, the utilities were both capital and skill intensive, but only a sixth of the firms surveyed were unionized. The other blue-collar nonmanufacturing industries-transportation/communication and mining - were likewise capital and skill intensive and shared high scores on welfarism, but they were highly unionized $50 \%$ of the capital-intensive firms and $57 \%$ of the skill-intensive firms were unionized; see NICB 1936). This suggests that early welfare work was driven by efforts to retain skilled employees in capital-intensive sectors rather than by unionism per se. Table 2, which reports every pension program that the NICB could locate in 1925 by industry, confirms this:

\footnotetext{
${ }^{5}$ While the NICB surveyed thousands of organizations, they only reported industrylevel figures and they disposed of the original questionnaires.

${ }^{6}$ Because the 1928 study reported interindustry data only for small firms, the 1935 data give a better picture of differences across industries. Note that the marginals for large firms changed little between these two panels, which suggests that most growth had occurred by 1928 and that the decline of these practices had not yet begun.
} 
TABLE 1

Prevalence of Benefits by Industry and Year (\%)

\begin{tabular}{|c|c|c|c|c|c|c|c|c|c|c|c|c|c|c|c|c|c|}
\hline & & \multicolumn{4}{|c|}{$\begin{array}{l}\text { INFORMAL OR INDIVIDUAL } \\
\text { PENSIONS }\end{array}$} & \multicolumn{4}{|c|}{ Mutual Benefit Associations } & \multicolumn{4}{|c|}{ Group PENSIONS } & \multicolumn{4}{|c|}{ HEALTH/ACCIDENT INSURANCE } \\
\hline & & 1928 & 1935 & 1939 & 1946 & 1928 & 1935 & 1939 & 1946 & 1928 & 1935 & 1939 & 1946 & 1928 & 1935 & 1939 & 1946 \\
\hline \multicolumn{2}{|l|}{ Agricultural implements } & & 10.0 & 0 & & & 50.0 & 417 & & $\ldots$ & 20.0 & \multicolumn{2}{|l|}{250} & & 100 & \multirow{2}{*}{208} & \\
\hline Automobiles and parts. & . & & 21.9 & $(154)$ & 109 & & 315 & $(21,2)$ & 163 & & 0 & $(10)$ & 31.5 & & 53.4 & & 783 \\
\hline Aircraft and parts & & & & & 51 & & & & 103 & & & $(10)$ & 487 & & & $(538)$ & 872 \\
\hline \multirow{2}{*}{\multicolumn{2}{|c|}{$\begin{array}{l}\text { Chemicals and chemical products } \\
\text { Electrical manufacturing }\end{array}$}} & 151 & 316 & 406 & 116 & 48 & 263 & 180 & 72 & 4 & 140 & 203 & 60.8 & 95 & 342 & 438 & 674 \\
\hline & & . & 233 & 188 & 77 & & 289 & 231 & 88 & & 78 & 12.8 & 407 & & 289 & 40.2 & 608 \\
\hline \multicolumn{2}{|l|}{$\begin{array}{l}\text { Electrical manufacturing } \\
\text { Food products ... }\end{array}$} & 48 & 336 & 295 & 146 & 2 & 257 & 17.9 & 8.1 & 0 & 15.0 & 16.7 & 54.0 & 87 & 336 & 314 & 611 \\
\hline & . & 27 & 213 & 14.0 & 155 & 48 & 240 & 26.6 & 138 & .0 & 27 & 4.7 & 259 & 80 & 307 & 281 & 707 \\
\hline \multicolumn{2}{|l|}{ Lumber and its products } & 40 & 123 & 140 & & 56 & 160 & 17.4 & & 0 & 9 & 33 & & 94 & 264 & 405 & \\
\hline \multicolumn{2}{|l|}{ Building materials and supplies . . } & . & & & 93 & & & & 112 & & & & 318 & . & . & & 953 \\
\hline \multicolumn{2}{|l|}{ Machines and machine tools } & . & 186 & 238 & 95 & & 37.1 & 342 & 121 & & 57 & 50 & 391 & & 258 & 292 & 69.6 \\
\hline \multicolumn{2}{|l|}{ Metals and metal products } & 39 & 210 & 226 & 113 & 57 & 306 & 236 & 105 & 2 & 6.5 & 67 & 318 & 117 & 33.5 & 381 & 643 \\
\hline \multirow{2}{*}{\multicolumn{2}{|c|}{$\begin{array}{l}\text { Paper and its products } \\
\text { Petroleum and its products }\end{array}$}} & 67 & 323 & 358 & 14.3 & 45 & 31.0 & 246 & 148 & 0 & 5.2 & 45 & 371 & 15.2 & 490 & 440 & 757 \\
\hline & & & 135 & 213 & 38 & & 351 & 277 & 154 & & 297 & 511 & 731 & & 29.7 & 426 & 731 \\
\hline \multicolumn{2}{|l|}{ Printing and publishıng } & 49 & 22.1 & 296 & 156 & 58 & 279 & 245 & 189 & 13 & 93 & 13.3 & 356 & 133 & 279 & 347 & 633 \\
\hline \multirow{2}{*}{\multicolumn{2}{|c|}{$\begin{array}{l}\text { Rubber } \\
\text { Stone, clay, and glass }\end{array}$}} & 107 & 125 & 211 & 102 & 36 & 300 & 158 & 68 & 0 & 75 & 53 & 390 & 143 & 47.5 & 526 & 729 \\
\hline & & & 212 & 220 & & . & 4.5 & 140 & & & 15 & 90 & & & 318 & 31.0 & \\
\hline \multirow{2}{*}{\multicolumn{2}{|c|}{$\begin{array}{l}\text { Glass . . } \\
\text { Textiles and clothıng }\end{array}$}} & . & & & 74 & & & & 37 & & & . & 407 & . & & & 556 \\
\hline & & 32 & 228 & 231 & 152 & 22 & 213 & 134 & 68 & .2 & 55 & 56 & 280 & 119 & 181 & 23.5 & 672 \\
\hline \multicolumn{2}{|l|}{ Manufacturing industries } & 47 & 227 & 245 & 116 & 44 & 276 & 225 & 104 & 2 & 70 & 88 & 376 & 109 & 31.2 & 35.6 & 669 \\
\hline \multirow{2}{*}{\multicolumn{2}{|c|}{$\begin{array}{l}\text { Banking } \\
\text { Insurance }\end{array}$}} & & 150 & 226 & 75 & & 25 & 48 & 0 & & 375 & 51.6 & 785 & . & 100 & 129 & 139 \\
\hline & & . & 15.4 & 333 & 111 & & 77 & 71 & 37 & & 462 & 595 & 759 & & 308 & 238 & 426 \\
\hline $\begin{array}{l}\text { Insurance } \\
\text { Gas and electricity }\end{array}$ & & 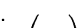 & 377 & 385 & 58 & & 420 & 319 & 198 & & 40.6 & 505 & 843 & & 348 & 38.5 & 446 \\
\hline \multicolumn{2}{|l|}{ Transportation and communication } & 95 & 243 & 167 & & 95 & 324 & 244 & & 0 & 486 & 385 & & & 405 & 34.6 & \\
\hline \multirow{2}{*}{\multicolumn{2}{|c|}{$\begin{array}{l}\text { Transportation ... } \\
\text { Communication and broadcasting }\end{array}$}} & & & & $143(107)$ & & & $\cdot$ & 306 & & & & $612(666)$ & & 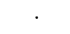 & . & $388(480)$ \\
\hline & & & & & $38(107)$ & & & & $38 \quad 213$ & & & & $769\left(\begin{array}{lll}00 & 0\end{array}\right)$ & & & & $654(400)$ \\
\hline \multirow{2}{*}{\multicolumn{2}{|c|}{$\begin{array}{l}\text { Wholesale and retail trade } \ldots \\
\text { Mining }\end{array}$}} & 10 & 421 & 402 & 179 & 4.1 & 513 & 320 & 236 & 10 & 66 & 113 & 538 & 20 & 211 & 186 & 396 \\
\hline & & & 321 & 238 & & & 286 & 71 & & & 71 & 48 & & 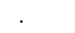 & 107 & 310 & \\
\hline \multicolumn{2}{|l|}{ Coal and coke } & & & & 185 & & & & 111 & & & & 296 & & & & 630 \\
\hline Nonmanufacturing industries & & 38 & 294 & 299 & 113 & 62 & 324 & 211 & 146 & 8 & 309 & 343 & 674 & 62 & 27.6 & 270 & 389 \\
\hline $\begin{array}{c}\text { All industries (firms with fewer } \\
\text { than } 250 \text { employees) } \\
\text { All industries (firms with } 250\end{array}$ & & 46 & 159 & 146 & 74 & 4.5 & 168 & 108 & 39 & 2 & 39 & 60 & 248 & 110 & 245 & 257 & 533 \\
\hline or more employees) & . & 264 & 274 & 305 & 12.7 & 297 & 340 & 279 & 133 & 19 & 134 & 161 & 475 & 155 & 338 & 383 & 672 \\
\hline
\end{tabular}

Note.-Industry-specific and sectoral data for 1928 pertain only to firms with 250 or fewer employees. Several industries have been collapsed to facilitate comparisons over time: textiles and clothing are combined; "chemicals" includes drugs, dyes, paints, pigments, varnishes, soap, and toilet preparations; and "metals and metal products" includes iron and steel and nonmachine metal products. For some other industries that could not be collapsed to match over time, percentages are reported within parentheses that span several categories in problematic years (e.g., transportation, communication, and broadcasting). Marginals by sector and size include some industrial categories not listed here. 
TABLE 2

Number of Pension Plans in Operation by Industry, 1925

\begin{tabular}{|c|c|c|c|c|}
\hline & \multirow[b]{2}{*}{$\begin{array}{c}\text { CONTRIBUTORY } \\
\text { (INSURED) }\end{array}$} & \multicolumn{2}{|c|}{ NONCONTRIBUTORY } & \multirow[b]{2}{*}{ TOTAL } \\
\hline & & Discretionary & $\begin{array}{c}\text { Limited } \\
\text { Contractual }\end{array}$ & \\
\hline Chemicals ................. & 1 & 5 & 4 & 10 \\
\hline Food $\ldots \ldots \ldots \ldots \ldots \ldots \ldots$ & 3 & 3 & 0 & 6 \\
\hline Metals ................... & 5 & 38 & 17 & 60 \\
\hline Paper and printing ........ & 0 & 8 & 1 & 9 \\
\hline Petroleum ................ & 0 & 3 & 8 & 11 \\
\hline Textiles $\ldots \ldots \ldots \ldots \ldots \ldots$ & 1 & 6 & 0 & 7 \\
\hline Miscellaneous ............. & 2 & 3 & 4 & 9 \\
\hline Banking $\ldots \ldots \ldots \ldots \ldots \ldots$ & 9 & 8 & 0 & 17 \\
\hline Insurance $\ldots \ldots \ldots \ldots \ldots \ldots$ & 0 & 8 & 0 & 8 \\
\hline Mining $\ldots \ldots \ldots \ldots \ldots \ldots \ldots$ & 1 & 4 & 1 & 6 \\
\hline Railroads ................. & 1 & 36 & 0 & 37 \\
\hline Trade $\ldots . . . \ldots \ldots \ldots \ldots \ldots$ & 2 & 9 & 1 & 12 \\
\hline Utilities $\ldots \ldots \ldots \ldots \ldots \ldots \ldots$ & 2 & 37 & 7 & 46 \\
\hline Total $\ldots \ldots \ldots \ldots \ldots$ & 27 & 168 & 43 & 238 \\
\hline
\end{tabular}

SOURCE: NICB (1925, p. 15).

informal pensions were common in the highly unionized railway industry, but they were also common in the largely nonunion metals and utilities sectors (Wolman 1936). The relationship that some have found between unionism and welfare practices, then, may be spurious. Industries that were both capital and skill intensive could ill afford labor discontent, which made it difficult for them to fight unions and also spurred them to install welfare practices to placate workers.

Retail and wholesale firms were the most likely to use both welfare practices. Carter and Carter (1985, p. 590) suggest that large retail stores adopted welfare work practices because their profitability depended on presenting an affable, clean, and healthy face to the public (see also Nelson 1975; Labor Statistics Bureau 1917). By offering pension and health coverage, firms kept ill and superannuated employees at home. At first glance that thesis seems to be challenged by the fact that in white-collar banking and insurance firms, which likewise depended on customer relations, informal pension plans were rare and mutual benefit associations were unheard of. Table 1 shows that those industries used formal pension insurance instead of informal pensions, yet for health insurance, banks reported the lowest use of any industry and the insurance industry itself reported only average use. Why did banking and insurance differ from trade in their use of health coverage? Contemporary 
studies found that, instead of offering health coverage, some one-half to two-thirds of banks and insurance companies guaranteed salary maintenance for injured or ill workers, but this practice was unworkable in wage-based industries where the time clock reigned (Baker 1940; NICB 1937).

Most analysts date the decline of welfare work to the Depression, arguing that once problems of turnover and union activism subsided, employers could ill afford to be charitable, and that Roosevelt's hardline stance against industrial paternalism discouraged welfarism (Brandes 1976; Brody 1980; Achenbaum 1986). Yet figure 1 shows no decline; on the contrary, both practices showed small increases among large firms (see table 1 above). Moreover, the 1935 study reports that only $4 \%$ of those firms that had used informal pensions had discontinued them and only $8 \%$ of those that had used mutual benefit associations had discontinued those (NICB 1936, p. 11; see also Parks 1936). Some health and pension welfare programs may have expired when firms went bankrupt and closed their doors, but few of the firms that endured canceled their programs. The 1939 figures show that, even after the Wagner Act had expanded union membership, firms did not abandon welfare practices.

Why, then, do analysts date the end of welfare practices to the Depression or to the Wagner Act? Sanford Jacoby (1984, p. 41) suggests that it is because paternalistic "old welfare work" practices such as housing programs, thrift plans (e.g., stock purchase programs through payroll deductions), recreational programs, and educational programs were discontinued, but "new welfare work" practices, which tied benefits to loyalty and job tenure (e.g., pensions and mutual benefit associations) actually grew. Indeed, the NICB found that among large firms home purchase plans declined by $48 \%$ between 1928 and 1935, company housing programs dropped by $28 \%$, and stock purchase plans fell by $56 \%$ (NICB 1929, 1936). But firms did not cancel health and pension forms of welfare work.

In sum, the argument that employers installed pension and health care forms of welfarism to quell turnover among skilled employees receives some support in the NICB data. Yet the evidence for arguments about labor turnover and union busting is mixed, because firms did not abandon these forms of welfarism either in the early thirties when labor turnover was no longer a problem, or in the late thirties after their employees had joined unions.

\section{Health and Pension Insurance}

The prevalence of employment-related health and pension insurance increased significantly between 1928 and 1935 (see table 1 and fig. 1). 


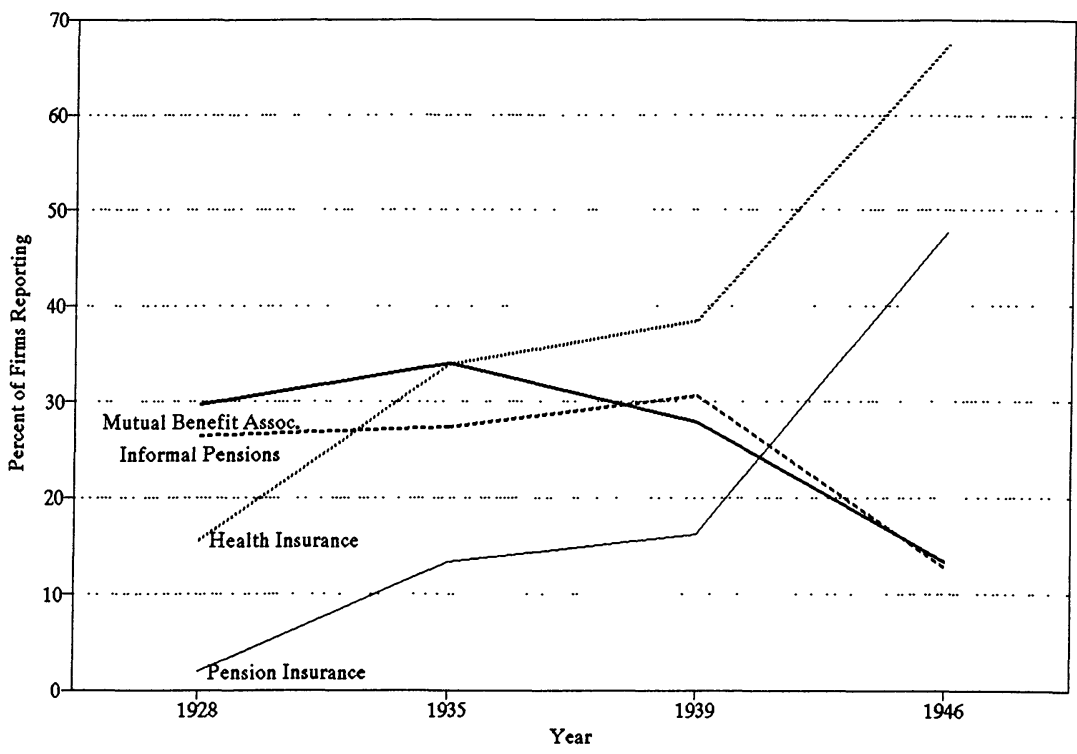

FIG. 1.-Pension and health benefits among large firms, 1928-46

Among the large firms surveyed, health/accident insurance more than doubled, from $16 \%$ to $34 \%$, and group pension plans rose from under $2 \%$ to over $13 \%$. In addition, existing pension and health insurance programs were seldom abandoned despite the unsteady economy. In its 1935 study the NICB found that only $7 \%$ of all pension and health insurance programs had been canceled since the onset of the Depression (NICB 1936, p. 11; see also Parks 1936). These trends belie every industrial explanation of the origins of insurance, because the Depression mitigated the problems associated with turnover, union activism, organizational growth, and labor-market segmentation. However, public policy had marked effects on the aims of the insurance industry, labor unions, and business groups, all of whom successfully promoted private insurance at the organizational level and provided weak support for social insurance.

\section{Public Policy and Interest Group Goals}

Three important groups promoted private health and pension insurance during the twenties and early thirties; their support can be traced, broadly, to institutional context and, in a more specific sense, to public policy. The industrial revolution brought huge firms and enormous unions to the United States in the latter decades of the 19th century, but the American state remained singularly weak and disorganized. It was 
clear that the state would be unwilling, and unable, to provide adequate social insurance coverage for industrial workers, and unions and businesses soon stepped in to fill the gap by providing coverage of their own. American Express introduced pension coverage in 1875, and by 1925 over 200 large firms were offering pensions (NICB 1925, 1929; National Personnel Association 1922, p. 6). Health and accident coverage was first offered in the dangerous mining and railway industries by benevolent societies that soon evolved into unions (Brandes 1976). Business and labor groups that had developed their own forms of insurance opposed social insurance, such as the state health programs advocated by Progressive reformers in the 1910s, so that by the mid-thirties only private health and pension coverage existed (Anderson 1985, pp. 66-73). Meanwhile, in the 1800 s a large life insurance industry, which surpassed European insurance industries in size and sophistication, grew up alongside new industrial enterprises with the encouragement of state legislatures (Zelizer 1979). By the early 1930s, their experiences with private insurance turned insurers, unions, and business leaders into effective supporters of private coverage.

The insurance industry strategy. - The presence of a large insurance industry, with sophisticated actuarial techniques, that was poised to expand insurance coverage during the Depression contributed to the growth of private health and pension insurance. The Depression proved to be an unexpected boon to the insurance industry, whose assets increased by one-third between 1929 and 1935, in part because of the increased economic insecurity during that period (James 1947, p. 293). While large insurers saw declines in their commercial business, they also saw substantial increases in group insurance plans for employees. The number of companies writing health and accident insurance rose by $20 \%$ between 1929 and 1931 alone (Insurance Almanac 1930, p. 1189; 1932, p. 1016). For 1931, the eight largest group insurers reported that one-third of their premium income came from group insurance other than life insurance, such as health and pension insurance, compared with only $1 \%$ from this source in 1926 (Bureau of Labor Statistics 1932-43 [1932, p. 53]).

The increasing popularity of income-protection insurance was partly a result of the new sales strategies insurers adopted during the Depression. Insurers encouraged salesmen to cast health and accident coverage as "income insurance" that would guard families against destitution (Tiger 1932 , p. 11; Landers 1935 , p. 13). In response to a $250 \%$ increase in disability claims against life policies during the early Depression, the major insurance firms separated life and disability coverage and began offering these popular forms of coverage in low-cost package deals that included pension and health coverage as well (NICB 1934, p. 36; Bureau 
of Labor Statistics 1932-43 [1933, p. 54]; Stone 1957, p. 154). Insurance companies also encouraged employers to sustain coverage for employees by (a) using "work sharing" instead of layoffs, which helped to keep employees on the insurance rolls, and $(b)$ continuing to pay premiums during temporary plant shutdowns to prevent policy cancellation (Bureau of Labor Statistics 1932-43 [1933, p. 53]). Among insurers, industry publications encouraged firms to try to replace their lost commercial business with these forms of coverage. By 1935 an industry trade journal suggested that a "'well balanced' agency should have at least a third of its casualty premiums in the health and accident line" (Rough Notes 1935, p. 11).

While they were promoting private insurance at the firm level, insurance industry leaders were lobbying Congress for Social Security legislation that would favor the industry. They promoted an amendment that would exempt employers with private insurance schemes from Social Security taxes, with the goal of shaping legislation that would cause most employers to adopt private insurance. $\mathrm{H}$. Walters Forster, a partner in a Philadelphia agency specializing in group annuity coverage, organized a massive campaign among insurance industry executives and employers in support of this amendment, but President Roosevelt insisted on public coverage, and in the Senate committee the final vote was a tie, which kept the amendment out of the act (Witte 1962, p. 161).

Union goals.-On the other hand, AFL leadership, under Samuel Gompers, favored private benefits programs consistently until 1932, even though some AFL locals had come to support social insurance instead. Gompers's position can be traced to two factors. First, he preferred union-provided insurance because he believed that union health benefits won members. His own union career had begun with the cigar makers in New York, where he proposed union sickness and death benefits in the late 1870s and saw a tenfold increase in membership (Starr 1982, p. 249). Railway unions, which had their roots in benevolent societies formed to protect members against calamity, shared Gompers's sentiments. Of course, those union benefit programs had appeared in the first place to make up for the absence of public social insurance.

Second, Gompers and other AFL leaders were suspicious of proposals for public coverage because federal policy in the teens and twenties had been so firmly antiunion. Thus in 1916 Gompers not only failed to lobby for social insurance legislation, he testified against it before the House Committee on Labor (Anderson 1985). The legacy of early union benefit programs and the federal government's antiunion stance was an American union movement led by men who opposed social insurance and favored private protection (Achenbaum 1986, p. 84; Witte 1962). 
Business preferences. - Business leaders had briefly advocated social insurance in the teens, but they soon switched their support back to private coverage. European business leaders in skilled, highly paid industries often supported social insurance because it shifted responsibility for coverage to the state, so it is somewhat surprising that their American counterparts largely backed private coverage.

The record suggests that high-wage employers backed private insurance schemes for the same reason Gompers did; they believed they had won worker allegiance by offering benefits (Quadagno 1984, p. 636). Firms at the forefront of welfare capitalism, such as Western Electric, had first installed welfare programs to win the hearts and minds of employees and had apparently achieved success. Consequently, such business organizations as the National Association of Manufacturers, the Chamber of Commerce, and the National Civic Federation withdrew their support for public health coverage during the teens when members argued that employer-provided coverage served important labor control functions (Starr 1982, pp. 250-52; Anderson 1985, p. 86). That was the turning point for business support of state health insurance. In the 1920s, business associations (NICB 1925) and government agencies (Bureau of Labor Statistics 1928) promoted the idea that fringe benefits could increase productivity and help control labor dissent (Berkowitz and McQuaid 1980, pp. 82-84).

In the 1920s, industrial relations professionals, echoing welfare capitalists, argued that health insurance was an effective antiunion device because it demonstrated the goodwill of the employer and circumvented the union bargaining process. Auto industry firms, for instance, had introduced health coverage to undermine the efforts of the United Auto Workers, an organization adamantly opposed to unilateral fringe-benefit programs because they interfered with the union's role of representing the workers (Munts 1967, p. 9). General Motors introduced a group health insurance plan in 1926, finding that when unions objected to the plan they alienated prospective members (Munts 1967, p. 48). This strategy of using benefits to quell unionism was widely promoted in the contemporary literature on union avoidance. Accordingly, in table 1 we find that industries that faced the most active union organizing effortsautos, paper, and rubber-show remarkable rates of private health coverage (NICB 1940a; Pelling 1960). As early as 1928, the paper and rubber industries reported unusually high rates of health insurance coverage, and by 1935 autos, paper, and rubber reported rates that were nearly double the average and at least 13 percentage points higher than the next highest manufacturing industry (see table 1).

Recent policy shifts and business preferences. - Three contemporary 
policy changes encouraged firms to adopt private health and pension insurance. First, tax code changes in 1926 made corporate contributions to insured pensions deductible, and after the corporate tax increases of the early thirties this made insured pensions increasingly attractive (Schieber 1982; Stevens 1988). Indeed, between 1925 and 1935, insured pensions rose from $11 \%$ to $30 \%$ of all pensions (NICB 1925, 1936). Second, Roosevelt's New Dealers tried to put an end to welfare work first by prohibiting employers from requiring participation in "company unions," which were at the core of welfarism, in the National Industrial Recovery Act of 1932, and then by outlawing "company unions" altogether in the Wagner Act of July 1935 (Schlesinger 1958). Stuart Brandes argues that, on top of the economic exigencies of the Depression, this attack on company unions brought down "the whole array of welfare practices" (1976, p. 144). While we know that welfare work survived the early thirties, the antiwelfare stance of the New Dealers undoubtedly encouraged employers to choose health and pension insurance over uninsured plans (see fig. 1). In addition, the banking and insurance industries faced special federal incentives during these years. Expanded Depression-era regulation of financial institutions through the Securities and Exchange Commission and the Federal Deposit Insurance Corporation made banks and insurance companies accountable for their outlays. Because firms had difficulty justifying to federal regulators their informal, discretionary pension payments, many switched to insured pension schemes (Schlesinger 1958; Romasco 1983). Thus by 1935, 38\% of all banks and $46 \%$ of all insurance companies reported offering pension insurance (NICB 1936). These are among the highest rates of use for the time. Health insurance plans doubtless remained rare in those sectors because of the practice of salary continuation, which did not raise the eyebrows of auditors.

In sum, Depression-era industrial conditions do not seem to have put an end to welfare work or retarded the growth of employment-related insurance. Instead, American public policy, specifically the paucity of public income protections, had created a sophisticated insurance industry, ready to promote income-loss insurance during the Depression, and had led business and labor leaders to develop their own private forms of illness and pension coverage. Privately organized insurance schemes gained constituencies among union and business leaders, as Philip Selznick (1948) would predict, and those leaders came to prefer private forms of coverage to public forms in the twenties and early thirties. Finally, specific public policies encouraged firms to adopt insured benefits and to abandon informal benefit programs. As a result private insurance rose during the early years of the Depression. 


\section{THE LATE THIRTIES}

\section{The Social Security Act}

Policy analysts anticipated that Social Security and the Wagner Act would have marked effects on employment-related insurance. Social Security was expected to render private pension insurance obsolete, at least for nonmanagerial employees. By contrast, the Wagner Act led to a rise in unionism that was expected to result in the growth of all sorts of employment benefits (NICB 1936, 1940a). Yet table 1 shows almost no change in the aggregate figures for health and pension insurance between 1935 and 1939. Was insurance really stagnant over these years? A closer examination of the data illuminates some unanticipated consequences of the Social Security Act. The section on the war years, below, deals with the specific effects of the Wagner Act.

The NICB surveyed several hundred firms in 1939 to ascertain the effects of Social Security legislation on private pension schemes. It found that less than one-tenth of those offering private pensions in 1935 had canceled them by 1939. "This delay in making necessary adjustments may be explained by the constant agitation for certain fundamental changes in the law which began almost as soon as it became effective" (NICB 1939, p. 24). Roosevelt argued for the expansion of the Social Security Act while his opponents tried to get it declared unconstitutional in the courts; firms waited to see who would prevail.

However, the NICB data suggest that, in high-wage industries, the low Social Security benefit levels caused substantial numbers of firms to purchase private supplementary insurance without delay. The maximum benefits to be paid out by the old-age insurance program of Social Security were set below the minimum wage and were compressed. An employee who was earning $\$ 100$ a month and who was fully vested would receive $\$ 35$ a month upon retirement, or $35 \%$ of her regular wages. Yet an employee earning $\$ 250$ a month would receive only $\$ 56$ a month upon retirement, or $22 \%$ of her regular wages. Because benefits were limited to the first $\$ 3,000$ of wages, an employee earning $\$ 5,000$ annually would also receive $\$ 56$ monthly, or $13 \%$ of her regular pay (Ilse 1953, p. 297). Consequently, the NICB data show the greatest percentage gains in the use of insured pensions in industries with highly paid employees (Bureau of Economic Analysis 1986; NICB 1939). In the manufacturing sector, chemicals, electrical manufacturing, petroleum, and printing saw the greatest percentage increases in group pensions between 1935 and $1939^{7}$ - gains of at least $40 \%$. According to the 1940 census, these four

\footnotetext{
${ }^{7}$ This is true with the exception of three industries that saw large percentage increases because less than $3 \%$ of firms had pensions in 1935 .
} 
industries had at least twice as many professional and semiprofessional workers $(8.6 \%-10.2 \%)$ as other manufacturing industries $(0.6 \%-3.8 \%)$, with the exception of machines (10.2\%; Bureau of the Census 1940). ${ }^{8}$ These industries also reported wages that were $25 \%-45 \%$ above the national average in 1939 (Bureau of Economic Analysis 1986, p. 279). Many firms had held off adopting private pension schemes because they had anticipated federal coverage, but the passage of this weak public coverage evidently convinced those in high-wage sectors to wait no longer (NICB 1939; Ilse 1953). The effects of weak Social Security coverage can also be seen among banks, whose employees were excluded in the 1935 legislation. As a result, we see in table 1 that private pension coverage in banking increased 14 percentage points between 1935 and 1939. In short, in sectors where the Social Security Act provided the weakest pension coverage, passage spurred firms to adopt private plans. The architects of Social Security legislation had not anticipated that outcome. By 1939 the act had caused twice as many firms to install private pension programs as to cancel existing plans (NICB 1939, p. 24). Helen Baker, of Princeton's Industrial Relations Section, wrote in 1940 that the act had "encouraged rather than retarded voluntary action [private pension coverage] by the employer" (1940, p. 10).

The act also caused two-thirds of the firms that offered pension insurance in 1935 to replace it with supplemental insurance designed to dovetail with public coverage by 1939 (NICB 1939). Most of the new programs $(66 \%)$ were graduated, so that private pension coverage increased with income as a function of the decline in public coverage, which meant that employees would receive total retirement benefits equivalent to a flat percentage of their working income (NICB 1940b).

Social Security legislation also spurred firms with informal pension plans to update them, and in the process many switched to the contemporary insured (and tax-deductible) form of pension coverage. The NICB found that one-fourth of firms that used the old-style self-administered (informal) plans in 1935 had already switched to (formal) annuity plans by 1939 , yet no firms had made the reverse transition. In addition, $34 \%$ of operating group annuity plans had been changed from the older employer-paid form to joint contributions (nonrevocable), and only one company had made the reverse change (NICB 1939, pp. 25-26). The Amended Social Security Act of 1939 apparently reinforced this trend, as employers who were revising pension practices opted for the modern insured form (see table 1).

${ }^{8}$ The figure for agricultural implements was not published separately. The change in stone, clay, and glass probably represents a substantial change in glass, which is highly skilled, and less of a change in stone and clay, which are not. 
In sum, the passage of Social Security legislation had an unexpected positive effect on the prevalence of private pension insurance in selected sectors. Most firms delayed canceling private pension insurance, highwage firms installed supplementary plans, banks installed private pensions, and most firms that had pension plans replaced them with special supplemental plans, and, in the process, many switched from informal to insured pension plans.

\section{THE WAR YEARS}

The growth in group health and pension plans during the first half of the forties was astounding. Analysts have, quite naturally, pointed to effects of the war to explain these increases, but, in the light of the available historical evidence and the NICB data, current thinking about what went on during the war warrants several revisions. First, the interindustry data show little effect of turnover, labor-market segmentation, or increases in the size of organizations on the growth of insurance between 1939 and 1946. Insurance became more popular in every industry. Second, when it comes to public policy, the effects of wartime tax changes and wage controls have probably been overstated, yet the 1939 Social Security revisions had marked effects on the incidence of private pension programs. Third, pension and health insurance rose at a rapid rate in unionized sectors, but not because unions won benefits in their negotiations with employers. Instead, public policy, in the form of case law surrounding the Wagner Act, spurred employers to offer insurance unilaterally to subvert unionism; at the same time this caused unions to channel their energies toward winning the right to bargain over fringe benefits.

\section{Industrial Arguments}

Turnover. - While the economywide labor turnover rate increased dramatically during the war, from 3.2 monthly separations per 100 workers in September 1940 to a peak of 6.3 in September 1943, available interindustry data for the manufacturing sector in 1943 show no relationship with the prevalence of fringe benefits in 1946. The Bureau of Labor Statistics reported turnover rates for nine separate industries in 1943, at the peak of labor turnover, and the industries that had the highest turnover levels-shipbuilding, glass, cotton textiles, and clothing-showed average or below average levels of pension and health insurance in the NICB's 1946 study (the low turnover industries were aircraft, autos, metals, electrical machinery, and machinery; Bureau of Labor Statistics 1932-43 [1943, p. 1241]). Further, if benefits were indeed adopted to prevent wartime turnover we would expect munitions firms to have been 
the leaders, yet the shipbuilding, aircraft, explosives, and converted automobile industries reported overall pension and health insurance rates of $37 \%$ and $77 \%$, respectively. These rates are not substantially different from the aggregate figures for manufacturing, in which $38 \%$ of all manufacturing concerns offered pensions and $68 \%$ provided health insurance. Health insurance was slightly more prevalent there, but it had always been popular in these dangerous heavy manufacturing sectors. For instance, the automobile industry had the highest incidence of health insurance even in 1935.

The more diffuse effects of turnover throughout the economy are difficult to gauge; however, several factors suggest that employment stabilization was not the principal driving force behind the adoption of pension and health insurance. First, the war industries that grew the most (aircraft, shipbuilding, and the converted auto industry) paid well even before the war and did not have to devise new strategies to lure workers (Bureau of Economic Analysis 1986). Second, the federal government exercised a variety of controls, through agencies such as the War Production Board and the War Labor Board, that dampened turnover. These boards were most vigilant in munitions (Baron et al. 1986). Finally, as discussed below, the National War Labor Board (NWLB) wage freeze of 1942 was commonly circumvented, which meant that employers did not have to turn to nonwage forms of remuneration to attract workers.

Labor-market segmentation.-Widespread increases in fringe benefits appeared across all industrial sectors, which contradicts the notion that modern labor-market bifurcation had its roots in part in the divergence of benefit plans during this period. No matter how we categorize primary labor-market industries, they do not differ substantially from other manufacturing industries. In the aggregate, $38 \%$ of all manufacturing firms reported providing group pensions, and $68 \%$ offered health insurance in 1946. Core firms reported $39 \%$ and $70 \%$, respectively; capital-intensive firms likewise reported $39 \%$ and $70 \%$; and durable goods firms reported $36 \%$ and $69 \% .{ }^{9}$ While the large average firm size in the NICB studies may mean that the data represent core firms even in peripheral industries, other analyses of the NICB data have found marked sectoral differences in labor practices as predicted by labor segmentation theorists (Baron et al. 1986, 1988).

Organizational scale. - The number of employees in a firm appears to

${ }^{9}$ Core industries are aircraft, autos, chemicals, electrical goods, machinery, metals, and rubber (Hodson 1978; Gordon et al. 1982). Those with high capital-output ratios are lumber, chemicals, glass, metals, paper, petroleum, and printing (Kuznets 1961, pp. 214-15; Bureau of the Census 1947, p. 159). Durable goods industries are automobiles, aircraft, electrical manufacturing, building materials, machines, metals, stone, clay, and glass (Bureau of Economic Analysis 1986). 
be an excellent predictor of pension and health insurance coverage, a fact that supports the organizational maxim that increased scale is associated with increased formalization (Pugh et al. 1969; Blau and Schoenherr 1971). Turning again to table 1 , insured group pensions were nearly twice as prevalent in large firms as they were in small firms in $1946(47.5 \%$ vs. $24.8 \%$ ), and health insurance for large firms was 14 percentage points higher than it was for firms with fewer than 250 people. Yet the data contradict the idea that firms formalize certain practices once they reach a specific size and the corollary that aggregate increases in formalization over time are the direct result of increases in average firm size. In 1946, the percentages of small firms reporting pension (24\%) and health $(53 \%)$ coverage were greater than the percentages of large firms reporting that coverage in 1939 (16\% and 38\%, respectively). This suggests that historical factors are more important than size alone, even if large size increases the likelihood that an organization will adopt certain institutionalized practices.

\section{Public Policy Arguments}

Interindustry evidence suggests that wartime industrial problems do not account for increases in the prevalence of fringe benefits. How did the wartime wage freeze and tax code changes affect the incidence of private pension and health insurance? I will argue that policies that were intended to popularize insurance did not have that effect, and that policies that were not expected to popularize insurance did.

The $N W L B$ wage freeze.-Analysts of fringe benefits have frequently argued that the wartime wage freeze and changes in tax policy stimulated private benefit expansion (Munts 1967; Macaulay 1959; Stevens 1988). The outbreak of war in Europe quickened the American economy, increasing the bargaining power of unions and expanding labor conflict. Roosevelt responded by establishing the National War Labor Board in January 1942, the month following the Japanese attack on Pearl Harbor. The board's most momentous decision came that year in the "Little Steel" wage increase case. Bethlehem, Republic, Inland, and Youngstown steelworkers were demanding raises, but steel industry leaders wanted to stabilize wages and Roosevelt was seeking an economywide wage-price freeze. The NWLB decision was a compromise that tied wage increases to inflation, thereby freezing real wages, and the decision served as a precedent for firms throughout the economy (Seidman 1953; Civilian Production Administration 1947; Kerry 1980; Bureau of Labor Statistics 1932-43 [1940-43]). In 1943, the board ruled that pension and insurance benefits were not subject to the freeze. It is widely believed that this 
exemption spurred firms to increase benefits in lieu of increasing wages to attract and retain workers.

The Revenue Act of 1942. - The war brought a new tax code, designed in part to prevent war profiteering, which taxed up to $90 \%$ of any profits that exceeded prewar levels. This gave corporations a strong incentive to lower their taxable income. One effect of the law was to encourage new capital investment, but a number of analysts suggest that the excessprofits tax also created a compelling reason to expand tax-exempt fringe benefits. Because wage increases were limited by the NWLB freeze, employers could increase their deductible expenditures for labor only by expanding fringe benefits such as pension plans. Moreover, in 1943 the Internal Revenue Service (IRS) extended the tax-exempt status to payments for health insurance, which gave employers another vehicle to reduce pretax profits (Macaulay 1959). Stevens (1988) suggests that the wage freeze and the 1942 Revenue Act thus combined to help popularize fringe benefits. The result was a fivefold increase in employer contributions to pension trusts, from $\$ 171$ million in 1941 to $\$ 857$ million in 1945 (see also Munts 1967; Macaulay 1959; Ilse 1953; Quadagno 1988). For both workers seeking increased remuneration and employers trying to compete for personnel in an increasingly tight labor market, fringe benefits now offered an avenue for circumventing the wage freeze.

The record suggests that these policies came too late in the war to have caused the rises in pension and health insurance that we see between 1939 and 1946 (Stevens 1990). The Revenue Act of 1942 did not take effect until 1943; the NWLB did not begin to exempt benefits from the wage freeze until 1943; and the IRS extension of its pension-exemption policy to health insurance only took effect in 1944. While direct U.S. participation in the war effectively began in 1942, industry began gearing up for the war in 1939, and by 1943 employers had already made adjustments to retain workers. Indeed between 1939 and 1943, when new federal policies first took effect, employment rose by $49 \%$; it increased only another 4 percentage points to the wartime peak in 1944 (Bureau of Economic Analysis 1986, p. 275). Annual data on the number of insured American employees show conclusively that the bulk of the increases occurred before federal policy changes first took effect in 1943. The number of employees carrying group pension insurance rose from 720,000 in 1939 to 1.2 million in 1943 and to 1.47 million in 1946 (Ilse 1953, p. 315). The number carrying group health/accident insurance rose from 3.5 million in 1939 to 6.5 million in 1943 and to 7 million in 1946 (Ilse 1953, p. 189). ${ }^{10}$

${ }^{10}$ The figures for 1946 may be slightly deflated relative to those for 1943 because Ilse's source changed in 1945. As a result, between 1944 and 1945, Ilse's figures show a $4 \%$ 
Moreover the wage freeze probably had little effect even in the last two years of the war because firms found ways to circumvent it. Because raises were allowed in conjunction with promotions, as early as 1943 three out of five firms were paying wage increases for "in-grade progression," or promotions to progressively higher job titles within the same job-a practice that, because it discouraged turnover, was permitted by the NWLB (Jacoby 1985 , p. 264). The wage freeze, then, did not prevent employers from raising wages when they wanted to. This practice appears to undermine the wage freeze/tax increase argument because it enabled firms to retain valued workers and at the same time decrease before-tax profits without installing fringe benefits.

Analysts have reasonably assumed that these policy changes had the effects their authors intended. By exempting fringe benefits from the wage freeze Roosevelt's NWLB hoped to encourage the adoption of insurance coverage. The administration had expected that the taxdeductible status it extended to health insurance would foster fringebenefit programs. The architects of the 1942 Revenue Act included a clause requiring that tax-exempt pension programs cover $70 \%$ of employees and prohibiting discrimination against low-wage employees in order to encourage firms to expand private pension coverage. ${ }^{11}$ While these policies probably did encourage firms to install insurance programs, they came too late to have caused the massive wartime increases in fringe benefits.

\section{The Amended Social Security Act of 1939 and Business Strategy}

The 1939 amendments to Social Security appear to have had an unintended positive effect on private pension programs that has not been documented in the recent literature. The act as amended encouraged employers to favor private insurance plans for several reasons. On the one hand, the 1939 amendments made it clear to employers who were awaiting Roosevelt's promised benefit increases that those increases would not be soon forthcoming. Employers felt compelled to adopt supplementary pension plans for highly paid employees. On the other hand, Social Security provided a foundation retirement wage, which made private pensions relatively cheap. Employers could now try to win the hearts of workers through pension programs without spending much money.

Roosevelt had hopes for an incremental expansion of Social Security

decline in pension coverage and a $9 \%$ decline in health coverage. But this has little effect on the overall picture.

${ }^{11}$ As Louise Ilse (1953) points out, programs that covered only employees who earned over $\$ 3,000$ were not considered discriminatory. 
after 1935, and the intent of the 1939 legislation was to liberalize coverage (Achenbaum 1986, p. 26). Thereafter benefits would be calculated on the basis of average income at the time of retirement rather than on total lifetime contributions; this was expected to increase pension income because employees typically reach peak earnings just before retirement. The 1939 law called for employees to be fully insured with as little as two years of participation in the plan, rather than 40 years, and the first benefits became payable in January 1940, rather than in January 1942 (Achenbaum 1986, p. 30). The amendments also called for benefits, but not contributions, to increase with each dependent and for dependent payments to continue after the death of the insured employee.

But federal pension insurance was a zero-sum game because fiscal conservatives in Congress refused to increase total expenditures. Liberalizing entitlements meant that projected benefits per recipient would not rise significantly (Achenbaum 1986, p. 34). The 1939 act also postponed a scheduled increase in contributions that might have permitted benefits to rise with inflation. While the 1939 legislation called for a slight increase in projected benefits, it would be over a decade before Congress approved new increases.

Had benefits been set at a fixed percentage of income, inflation would have had no effect in real dollars. Instead, the benefit structure caused projected payments to retirees to decline dramatically in real terms between 1939 and 1946 as average wages doubled. First, the plan covered only the first $\$ 3,000$ of income. For a person who earned $\$ 3,000$ in 1939 and whose income doubled by 1946, the maximum monthly benefit of $\$ 56$ declined from $22 \%$ to $11 \%$ of working income. A growing number of Americans crossed the $\$ 3,000$ threshold between 1935 and 1946, as that figure declined from 2.6 to 1.26 times the average full-time income. Second, those who earned less than $\$ 3,000$ also lost in terms of projected benefits because the reverse-graduated plan dictated that benefits would decline, as a percentage of income, as income increased (NICB 1939, p. 41; Bureau of Economic Analysis 1986, p. 279). By failing to increase benefits in 1939 to counteract the effects of inflation, and by delaying an increase in contributions, Congress demonstrated that public coverage would not provide an adequate retirement wage.

Contemporary publications predicted a substantial increase in private plans in response to the 1939 amendments, and the data show such an increase (NICB 1939; 1940b). First, there is a remarkable aggregate increase; table 1 shows that between 1939 and 1946 the incidence of firms offering pensions rose from $7 \%$ to $38 \%$ in manufacturing and from $31 \%$ to $67 \%$ in nonmanufacturing. Second, data presented in table 3 suggest that there were large increases in supplemental pension plans for the managerial employees for whom Social Security benefits would replace 
TABLE 3

Percentage of Firms Reporting Group Pensions by Type of Plan, 1946

\begin{tabular}{|c|c|c|c|c|}
\hline & \multicolumn{3}{|c|}{ Firms Reporting Formal Plans } & \multirow[b]{2}{*}{$\begin{array}{c}\text { Total WITH } \\
\text { FoRMaL } \\
\text { PlaNS }\end{array}$} \\
\hline & $\begin{array}{c}\text { For } \\
\text { Wage } \\
\text { Earners }\end{array}$ & $\begin{array}{c}\text { For } \\
\text { Salaried } \\
\text { Employees }\end{array}$ & $\begin{array}{c}\text { For } \\
\text { Employees } \\
\text { Earning } \\
\text { over } \$ 3,000\end{array}$ & \\
\hline Manufacturing ............. & 22.8 & 31.1 & 13.7 & 37.6 \\
\hline Nonmanufacturing ....... & 43.8 & 64.0 & 28.2 & 67.5 \\
\hline All industries .............. & 25.7 & 35.6 & 15.7 & 41.7 \\
\hline
\end{tabular}

only a small proportion of working income. By 1946 firms were 50\% more likely to offer pensions to salaried workers than to wage earners. Nearly a third of nonmanufacturing firms, where lower-level workers were frequently salaried, had installed special pension plans for employees whose earnings exceeded the $\$ 3,000$ Social Security ceiling - this was also true for $14 \%$ of manufacturing firms.

Finally, because federal policy did not require firms to bargain with unions over fringe benefits, employers tried to use benefits to discourage unionism. Industrial relations professionals were promoting private insurance as an antiunion device with the same rhetoric that had been used to sell welfare work. However, after unions won the right to bargain for benefits in the late forties, employers switched to support for Social Security increases, and they helped to win expanded Social Security benefits in the early fifties (Stevens 1990).

\section{Public Policy and Union Support for Fringe Benefits}

A number of analysts have argued that union agitation for coverage accounts for the remarkable increases in health and pension insurance during the war. Unfortunately, the NICB's studies do not present detailed data on the coverage of union workers, although there is some evidence that unionization was related to the presence of pension and health insurance (see tables 1 and 3). First, if we look cross-sectionally at 1935 we see that nonmanufacturing industries were more highly unionized ( $25 \%$ of all firms were unionized) than were manufacturing industries (10\% of all firms were unionized), and they were more likely to offer pension insurance $(31 \%$ vs. $7 \%)$. Figures for health insurance were similar across the two sectors, despite the fact that many nonmanufacturing firms still depended on mutual benefit associations or salary maintenance. Second, increases over time in unionization are related to the number of 
TABLE 4

Percentage of Firms Reporting Union Contracts, by Sector and Size

\begin{tabular}{lcrccc}
\hline \hline & 1928 & 1935 & 1939 & 1946 \\
\hline Manufacturing $\ldots \ldots \ldots \ldots$. & 4.7 & 9.6 & 43.0 & 80.2 \\
Nonmanufacturing $\ldots \ldots \ldots$ & 3.8 & 25.0 & 45.3 & 59.5 \\
Small firms $\ldots \ldots \ldots \ldots \ldots \ldots$ & 4.7 & 7.3 & 32.3 & 67.8 \\
Large firms $\ldots \ldots \ldots \ldots \ldots \ldots$ & 5.5 & 13.9 & 48.6 & 80.5 \\
All industries/firms ........ & 4.9 & 11.7 & 43.4 & 77.3 \\
\hline
\end{tabular}

NoTE. - The 1928 sectoral figures are for small firms and the 1928 figure for all industries contains a higher proportion of small firms. Small firms are those with fewer than 250 employees; large firms have 250 or more employees.

employers who offer insurance. Between 1935 and 1946 unionization rose from $10 \%$ to $80 \%$ among surveyed manufacturing firms, and it rose from $25 \%$ to only $60 \%$ in nonmanufacturing (see table 4 ). Over that period both types of insurance underwent huge gains in manufacturing, but only pension insurance increased in nonmanufacturing areas (see table 1).

Unionization increased substantially in the aggregate over these years, and unions fought hard to win employment-related insurance even as they fought for the expansion of Social Security. Contemporary events suggest that public policy channeled union energies in the direction of private coverage. First, case law surrounding the Wagner Act entangled unions in a battle over the right to bargain for insurance coverage. The Wagner Act required firms to bargain with unions on the "wages and conditions of employment" without specifying whether "conditions" included benefits. Employers contended that "conditions" did not include benefits, and the courts backed them up until after the war, spurring a battle in the courtroom and at the workplace (Munts 1967, p. 10; Bernstein 1972). Unions, particularly the new Congress of Industrial Organizations (CIO) unions in the mass-production sector, fought the fringebenefit battle in the courts by demanding the legal right to represent members in negotiations for benefits and, at the organizational level, by demanding that employers include benefits in union contracts (Bernstein 1972; Quadagno 1988). Labor historians (e.g., Bernstein 1972) seem to concur that if the Wagner Act had not made benefits a point of contention, unions might have spent more of their energies backing the expansion of Social Security.

The sharp rise in insurance between 1939 and 1946, therefore, cannot be attributed to union-negotiated benefit plans. ${ }^{12}$ Only $4 \%$ of large firms

${ }^{12}$ By 1947 an estimated 1.5 million Americans were covered by union-negotiated health plans, some $90 \%$ of which were in the mining industry (which had experienced 
in the 1946 survey had union contracts which included any sort of insurance scheme, while $81 \%$ were unionized and $67 \%$ offered health insurance (NICB 1947). However there is strong evidence that firms frequently adopted fringe benefits either to subvert union organizing efforts or to appease unions, and, in fact, a number of unions won contractual promises that employers would not discontinue their unilateral benefit plans (Bernstein 1972; Munts 1967, p. 49).

Second, the form group pension insurance took after passage of Social Security legislation also contributed to union lobbying for expanded employment-related coverage. The 1939 amendments made it clear that even if some Democrats envisioned Social Security as a full-coverage pension program, in practice it served as a safety net that was inadequate without supplementary coverage. By 1939 most firms had adopted some sort of graduated private pension program that would make up the difference between Social Security benefits and a certain percentage of preretirement income (NICB 1939).

These programs were marketed by insurance companies, who devised "integrated" pension plans that guaranteed a certain combined publicprivate retirement wage in the hope that promised increases in public benefit levels would decrease projected insurance industry expenditures (Achenbaum 1986, p. 46). The structure of Social Security legislation and the projections for future benefit increases thus shaped the insurance industry strategy. The nature of these plans in turn influenced union strategy, because they had the effect of nullifying Social Security increases. For each dollar increase in monthly Social Security benefits, private supplemental benefits would decrease by a dollar. The 1942 Revenue Act then sanctioned this form of supplemental coverage by making it tax exempt, while it rendered other discriminatory pension programs taxable. These formulas encouraged the rank and file to fight for increases in the total benefit levels guaranteed by their private pension programs because they would gain nothing from Social Security increases (see Quadagno 1988). Thus the structure of Social Security benefits led unions to promote private fringe-benefit programs at the organizational level.

Union support for private pension insurance had in part been stimulated by congressional resistance to the idea of expanding Social Security. Likewise union support for employment-related health insurance was reinforced by the failure of a series of public health insurance bills in Congress. Early proponents of Social Security wanted health coverage

strikes and a federal takeover during the war) and the textile/clothing industry (where industrywide jointly managed funds were established in 1942 contracts; Goldmann 1948, p. 47; Munts 1967, pp. 13-28). Those successes are evident in table 1. 
included in the 1935 legislation, but acquiesced to fiscal conservatives in Congress. In 1939 Senator Robert Wagner introduced a bill that would have provided governmental health coverage for the needy, but that bill never came to a vote. In 1943 the Wagner-Murray-Dingell bill proposed universal and comprehensive health coverage to be administered under Social Security, but strong opposition from the American Medical Association (AMA) doomed it. In 1944 Roosevelt promoted an "economic bill of rights," which included the right to adequate medical care, and shortly after the end of the war Truman asked for national health insurance to cover all Americans, but the AMA defeated that bill as well (Anderson 1985; Berkowitz and McQuaid 1980; Starr 1982). Each defeat bolstered union support for private health coverage.

In sum, unions might have been expected to throw all of their support behind social insurance in the forties, but the Wagner Act and congressional opposition to the growth of Social Security kept them fighting for fringe benefits as well. When unions won the right to bargain over benefits in the 1947 Inland Steel decision, they did not give up on fringe benefits; on the contrary, having just lost ground in the Taft-Hartley Act, unions were anxious to demonstrate their newfound powers by winning fringe-benefit increases.

Alternative union strategies.-Historical factors produced unusual union strategies in certain sectors. These strategies led to substantially different kinds of benefit systems. An examination of several examples suggests that had public policy created a different set of incentives for unions in all industries, the outcome might have been a very different system of pension and health coverage throughout the economy.

First, AFL and CIO unions pursued markedly different strategies when it came to health benefits. The skilled AFL unions had traditionally sought to maximize their control over such matters as hiring and apprenticeships, and many AFL leaders still preferred to control member benefits directly through their own pension schemes and mutual benefit associations (Brandes 1976; Quadagno 1988, p. 160). By contrast the industrial CIO unions generally sought to formalize employment rights, and they backed employer-provided insurance schemes with nonrevokable rights to benefits. Consequently, mutual benefit associations survived in AFLdominated industries, and health insurance prevailed in CIO-dominated industries. Those relationships became stronger during the war, despite the overall decline in welfare programs and the rise of insurance. Note that AFL unionism correlates .24 with mutual benefit association usage in 1935 (before the establishment of the CIO), .33 $(P<.10)$ in 1939 , and $.40(P<.05)$ in 1946 (see table 5). By contrast, CIO unionism correlates .29 with health insurance coverage in 1939 , and $.61(P<.01)$ in 1946 , 
TABLE 5

Correlations of AFL and CiO Unionism with Health Coverage

\begin{tabular}{|c|c|c|c|c|c|}
\hline & \multirow{2}{*}{$\frac{1935}{\text { Unionism }}$} & \multicolumn{2}{|c|}{1939} & \multicolumn{2}{|c|}{1946} \\
\hline & & AFL & CIO & AFL & CIO \\
\hline Mutual benefit association ......... & .24 & $.33 \dagger$ & -.03 & $.39 *$ & .15 \\
\hline Health insurance ................... & .12 & .14 & .29 & .12 & $.61^{* *}$ \\
\hline
\end{tabular}

Note. - The CIO did not exist in 1935.

$\dagger P<.10$.

$* P<.05$.

$* * P<.01$.

at which time it also correlates $.38(P<.05)$ with hospitalization insurance. ${ }^{13}$ Here the different strategies of AFL and CIO unions had clear effects on fringe-benefit development, even if unions did not yet receive contractual rights to negotiate for health insurance.

Second, the railway industry shows evidence of what American pension and health coverage might have looked like had unions in more industries pursued the strategy of providing insurance themselves. Evidence from railroads and mining suggests that union-sponsored benefits precluded the adoption of employer-provided insurance. Railway unions had first been organized as benevolent societies and had long provided death, sickness, and old-age benefits for members. By 1931, railway unions paid out more in sickness benefits and in old-age pensions than did unions in any other industry - half as much as all other unions combined (Bureau of Labor Statistics 1933, pp. 313-31). Union health coverage provided an alternative to company benefits, hence table 1 shows that among transportation/communication firms, company pensions and health insurance declined between 1935 and 1939. By 1946 transportation reported the lowest incidence of offering health insurance of any industry, with the exception of banking, where salary maintenance programs were still used as a substitute. In contrast, mining unions had provided death benefits, but seldom offered pension or sickness coverage, and table 1 indicates that pension and health insurance had expanded significantly for miners by 1946 . The success of union-provided insurance among railways suggests that if unions in other sectors had installed

${ }^{13}$ Correlations use the original industrial categories from the NICB reports. Note that only industry-level data were available, hence these correlations represent the relationships between unionism and benefits among industries, not firms. In order to maximize the number of cases in each panel (26 in 1935, 25 in 1939, and 32 in 1946) I have not regrouped the industries to make them comparable over time. 
insurance schemes before corporations did so, as Samuel Gompers advocated, union-provided insurance schemes might have proliferated during the war and become the norm in American industry.

\section{CONCLUSION}

\section{Industrial Arguments}

Data collected by the NICB largely contradict the received wisdom that industrial factors and wartime public policies stimulated the growth of fringe-benefit programs. Early interindustry differences suggested that firms with skilled workers were most likely to adopt fringe-benefit packages and that organizational scale was associated with an industry's offering fringe benefits. Yet the experiences of the thirties tend to discount industrial arguments, because despite the fact that the problems normally associated with unionism-labor turnover, organizational scale, and labor-market segmentation-were mitigated during this period of economic crisis, the incidence of pension and health insurance increased. Furthermore, interindustry data from the forties suggest that these industrial problems were not related to increases in the prevalence of fringe benefits.

\section{Institutional Theory and Interest Group Goals}

I have developed an alternative institutional explanation that links public policy to interest group goals and in turn to organizational outcomes. The findings presented here underscore the power of an institutional approach that treats interest group goals as an intermediate variable between environmental context and organizational outcomes. As expected, union and business groups did not pursue consistent, predictable goals in the realms of health and pension coverage; rather, public policy shifts caused union and business goals to vary over time, and those groups were clearly instrumental in popularizing private insurance. Previous organizational studies have provided important evidence of the effects of the policy environment on group goals and organizational outcomes (Fligstein 1990; Baron et al. 1986), and here I have tried to extend that perspective by looking at the effects of public policy on the shifting goals of all major groups. In addition to providing a contextual framework for understanding group interests, this approach highlights the importance of recognizing that a group may pursue a single end alternately at the organizational level and at the political level.

The broad institutional context of American industrial and state development clearly contributed to union and business preferences for private 
forms of coverage. America's early industrial development led to the rise of sophisticated corporate bureaucracies; however, the development of the federal bureaucracy was comparatively slow (Chandler 1990; Skowronek 1982). As a result firms and unions experimented with private insurance long before Washington considered getting into the act, and when these groups discovered labor control functions in private coverage they became reluctant to relinquish control to the state. In Philip Selznick's (1948) terms, these practices had developed organizational constituencies that would fight for them in the future. This set the groundwork for the situation in the teens and twenties, when both business and labor leaders advocated private forms of insurance. Weak public protections had also stimulated the development of a large and sophisticated insurance industry that would promote employment-related health and pension coverage during the economic downturn of the thirties.

The strength and consistency of union support for private insurance is particularly surprising. Before the early thirties, the AFL leadership supported union-provided coverage instead of public coverage, because they believed that coverage increased member loyalty. After 1935 unions fought for employer-provided insurance because public policy made union bargaining rights a point of contention. Finally, during the forties the popularity of federally approved supplemental pension insurance plans bolstered union support for the expansion of private benefits because the supplemental plans canceled out increases in public coverage.

\section{Intended and Unintended Consequences of Public Policy}

Public policies that were expected to increase the incidence of private insurance did not always succeed. There were, however, some policies that did achieve this end without being designed to do so. Wartime tax and wage policies were certainly intended to help diffuse employerprovided insurance, but by tracing the empirical effects of those policies I have shown that they appeared after the wartime rise in fringe benefits. Instead, Social Security legislation boosted employment-related pension insurance by institutionalizing retirement without providing an adequate retirement wage. The original Social Security Act of 1935 had a marked effect on the prevalence of private pensions in high-wage sectors and also caused firms to rewrite their pension plans. Moreover, the 1939 amendments to the act gave a substantial boost to private insurance schemes because they expanded eligibility without raising contributions. Social Security revenues could not support the benefit increases that Roosevelt had originally hoped for, and when benefits were decimated by inflation, corporations responded by installing private supplementary pension programs. The failure of several proposals to extend Social Secu- 
rity to include health insurance had a similar effect on private health/ accident coverage.

The demise of welfare programs was in part wrought by these same policies, not by the economic exigencies of the Depression era. Health and pension forms of welfare work rose during the early Depression. But these forms declined after 1935 as firms responded to Social Security legislation by replacing their antiquated informal pension programs with modern supplementary insurance. Both forms of welfare coverage fell prey to the struggle over the interpretation of the Wagner Act, which led firms to offer insured fringe benefits outside of the union bargaining process.

Finally, while this article has focused on the factors that contributed to the growth of private employment-related insurance, the perspective employed here can inform institutional studies of state policy formulation as well. It should be clear, for instance, that the factors that shaped labor, business, and insurance industry goals vis-à-vis firm-level insurance coverage also shaped their goals vis-à-vis social insurance legislation, and the events of the forties clearly set the course for the future of social insurance (Amenta and Skocpol 1988). While some institutional studies of politics have analyzed how institutional factors affect the capacities of different groups to prevail in political struggles (Weir and Skocpol 1983), institutionalists have largely ignored how institutional context shapes the goals groups pursue in the first place.

\section{REFERENCES}

Achenbaum, W. Andrew. 1986. Social Security: Visions and Revisions. Cambridge: Cambridge University Press.

Amenta, Edwin, and Theda Skocpol. 1988. "Redefining the New Deal: World War II and the Development of Social Provision in the United States." Pp. 81-122 in The Politics of Social Policy in the United States, edited by Margaret Weir, Ann Shola Orloff, and Theda Skocpol. Princeton, N.J.: Princeton University Press.

Anderson, Odin W. 1985. Health Services in the United States: A Growth Enterprise since 1875. Ann Arbor, Mich.: Health Administration Press.

Baker, Helen. 1940. Current Policies in Personnel Relations in Banks. Princeton, N.J.: Princeton University, Industrial Relations Section.

Baron, James N., Frank R. Dobbin, and P. Devereaux Jennings. 1986. "War and Peace: The Evolution of Modern Personnel Administration in U.S. Industry." American Journal of Sociology 92:350-83.

Baron, James N., P. Devereaux Jennings, and Frank R. Dobbin. 1988. "Mission Control: The Development of Personnel Systems in U.S. Industry." American Sociological Review 53:497-514.

Berkowitz, Edward, and Kim McQuaid. 1980. Creating the Welfare State: The Political Economy of Twentieth-Century Reform. New York: Praeger.

Bernstein, Irving. 1972. The Turbulent Years: A History of the American Worker, 1933-1941. Boston: Houghton-Mifflin. 
Blau, Peter M., and Richard A. Schoenherr. 1971. The Structure of Organizations. New York: Basic.

Brandes, Stuart D. 1976. American Welfare Capitalism, 1880-1940. Chicago: University of Chicago Press.

Brody, David. 1980. Workers in Industrial America. New York: Oxford University Press.

Bureau of Economic Analysis. 1986. The National Income and Product Accounts of the United States, 1929-1982. Washington, D.C.: Government Printing Office.

Bureau of Labor Statistics. 1928. "National Conference on Mutual Benefit Associations." Monthly Labor Review 27:104-5.

- 1933. "Insurance, Benefit, and Pension Plans." Monthly Labor Review $36: 311-15$.

-1932-43. Monthly Labor Review.

Bureau of the Census. 1940. Sixteenth Census of the Population, vol. 1. Washington, D.C.: Government Printing Office.

- 1947. Census of Manufactures, 1947, vol. 6. Washington, D.C.: Government Printing Office.

Carter, Michael J., and Susan B. Carter. 1985. "Internal Labor Markets in Retailing: The Early Years." Industrial and Labor Relations Review 38:586-98.

Chandler, Alfred D., Jr. 1990. Scale and Scope: The Dynamics of Industrial Enterprise. Cambridge, Mass.: Harvard University Press.

Civilian Production Administration. 1947. Industrial Mobilization for War. Washington, D.C.: Government Printing Office.

DiMaggio, Paul J., and Walter W. Powell. 1983. "The Iron Cage Revisited: Institutional Isomorphism and Collective Rationality in Organizational Fields." American Sociological Review 48:147-60.

- 1991. Introduction to The New Institutionalism in Organizational Analysis, edited by W. Powell and P. DiMaggio. Chicago: University of Chicago Press.

Doeringer, Peter B., and Michael J. Piore. 1971. Internal Labor Markets and Manpower Analysis. Lexington, Mass.: Heath.

Edwards, Richard. 1979. Contested Terrain. New York: Basic.

Esping-Andersen, Gösta. 1990. The Three Worlds of Welfare Capitalism. London: Polity.

Fligstein, Neil. 1990. The Transformation of Corporate Control. Cambridge, Mass.: Harvard University Press.

Goldmann, Franz. 1948. Voluntary Medical Care Insurance in the United States. New York: Columbia University Press.

Gordon, David M., Richard Edwards, and Michael Reich. 1982. Segmented Work, Divided Workers. London: Cambridge University Press.

Hall, Peter. 1986. Governing the Economy: The Politics of State Intervention in Britain and France. New York: Oxford University Press.

Hodson, Randy. 1978. "Labor in the Monopoly, Competitive, and State Sectors of Production." Politics and Society 8:429-80.

Ilse, Louise. 1953. Group Insurance and Employee Retirement Plans. New York: Prentice-Hall.

Insurance Almanac. 1930. "Health Insurance in 1929." P. 1189 in Insurance Almanac. Englewood, N.J.: Underwriter.

- 1932. "Health Insurance in 1931." P. 1016 in Insurance Almanac. Englewood, N.J.: Underwriter.

Jacoby, Sanford. 1984. "The Development of Internal Labor Markets in American Manufacturing Firms." Pp. 23-69 in Internal Labor Markets, edited by Paul Osterman. Cambridge, Mass.: MIT Press.

- 1985. Employing Bureaucracy: Managers, Unions, and the Transformation of Work in American Industry, 1900-1945. New York: Columbia University Press. 
James, Marquis. 1947. The Metropolitan Life: A Study in Business Growth. New York: Viking.

Kerry, Tom. 1980. Workers, Bosses, and Bureaucrats: A Socialist View of Labor Struggles since the 1930s. New York: Pathfinder.

Krasner, Stephen D. 1984. "Approaches to the State: Alternative Conceptions and Historical Dynamics." Comparative Politics 17:223-46.

Kuznets, Simon. 1961. Capital in the American Economy. National Bureau of Economic Research. Princeton, N.J.: Princeton University Press.

Labor Statistics Bureau (Bureau of Labor Statistics). 1917. Proceedings of the Employment Managers' Conference, Philadelphia, April 2 and 3, 1917. Labor Statistics Bureau Bulletin 227. Washington, D.C.: Government Printing Office.

Landers, Jackson K. 1935. "How Accident Insurance Protects Incomes." Rough Notes 78:13-14.

Macaulay, Hugh. 1959. Fringe Benefits and Their Federal Tax Treatment. New York: Columbia University Press.

Meyer, John W., and Brian Rowan. 1977. "Institutionalized Organizations: Formal Structure as Myth and Ceremony." American Journal of Sociology 83:340-63.

Munts, Raymond. 1967. Bargaining for Health: Labor Unions, Health Insurance, and Medical Care. Madison: University of Wisconsin Press.

National Industrial Conference Board (NICB). 1925. Industrial Pensions in the United States. New York: NICB.

- 1929. Industrial Relations in Small Plants. New York: NICB.

- 1934. Recent Development in Industrial Group Insurance. New York: NICB. - 1936. What Employers Are Doing for Employees. New York: NICB.

1937. Personnel Practices Governing Factory and Office Administration. New York: NICB.

- 1939. Company Pension Plans and the Social Security Act. New York: NICB.

- 1940a. Personnel Activities in American Business. New York: NICB.

- 1940b. Company Pension Plans and the Amended Social Security ActComplete Texts and Digests. New York: NICB.

- 1947. Personnel Activities in American Business, rev. ed. New York: NICB.

. 1954. Personnel Practices in Factory and Office. New York: NICB.

National Personnel Association (NPA). 1922. Pensions for Industrial and Commercial Employees. New York: NPA.

Nelson, Daniel. 1975. Managers and Workers. Madison: University of Wisconsin Press.

Parks, Donald S. 1936. “1936 Personnel Trends." Factory Management and Maintenance 94:39-40.

Pelling, Henry. 1960. American Labor. Chicago: University of Chicago Press.

Perrow, Charles. 1986. Complex Organizations: A Critical Essay, 3d ed. New York: Random House.

Pugh, D. S., D. J. Hickson, C. R. Hinings, and C. Turner. 1969. "Dimensions of Organizational Structure." Administrative Science Quarterly 14:91-114.

Quadagno, Jill. 1984. "Welfare Capitalism and the Social Security Act of 1935." American Sociological Review 49:632-47.

- 1988. The Transformation of Old Age Security: Class in Politics in the American Welfare State. Chicago: University of Chicago Press.

Rein, Martin. 1982. "The Social Policy of the Firm." Policy Sciences 14:117-35.

Romasco, Albert U. 1983. The Politics of Recovery: Roosevelt's New Deal. New York: Oxford University Press.

Rough Notes. 1935. "Sell Accident or Disability Insurance: Dig a Gold-Nugget from Your File of Present Clients." Rough Notes 78:11-23.

Schieber, Sylvester J. 1982. Social Security. Washington, D.C.: Employee Benefit Research Institute. 
Schlesinger, Arthur M., Jr. 1958. The Coming of the New Deal. Boston: Houghton Mifflin.

Seidman, Joel. 1953. American Labor from Defense to Reconstruction. Chicago: University of Chicago Press.

Selznick, Philip. 1948. "Foundations of the Theory of Organization." American Sociological Review 13:25-35.

Skowronek, Stephen. 1982. Building a New American State: The Expansion of National Administrative Capacities, 1877-1920. Cambridge: Cambridge University Press.

Slichter, Sumner. 1961. Potentials of the American Economy: Selected Essays of Sumner H. Slichter. Cambridge, Mass.: Harvard University Press.

Starr, Paul. 1982. The Transformation of American Medicine. New York: Basic.

Stevens, Beth. 1988. "Blurring the Boundaries: How the Federal Government Has Influenced Welfare Benefits in the Private Sector." Pp. 123-48 in The Politics of Social Policy in the United States, edited by Margaret Weir, Ann Shola Orloff, and Theda Skocpol. Princeton, N.J.: Princeton University Press.

- 1990. "Labor Unions, Employee Benefits, and the Privatization of the American Welfare State." Journal of Policy History 2:233-60.

Stone, Mildred. 1957. Since 1845: A History of the Mutual Benefit Life Insurance Company. New Brunswick, N.J.: Rutgers University Press.

Tiger, E. S. 1932. “'Income Insurance' Cornerstone." Rough Notes 75:11-13.

Tolbert, Pamela, and Lynne G. Zucker. 1983. "Institutional Sources of Change in the Formal Structure of Organizations: The Diffusion of Civil Service Reforms, 1880-1935." Administrative Science Quarterly 23:22-39.

Weir, Margaret, and Theda Skocpol. 1983. "State Structures and Social Keynesianism." International Journal of Comparative Sociology 24:4-29.

Witte, Edwin. 1962. The Development of the Social Security Act. Madison: University of Wisconsin Press.

Wolman, Leo. 1936. Ebb and Flow in Trade Unionism. New York: National Bureau of Economic Research.

Zelizer, Viviana. 1979. Morals and Markets: The Development of Life Insurance in the United States. New York: Columbia University Press.

Zysman, John. 1983. Governments, Markets, and Growth: Financial Systems and the Politics of Industrial Change. Ithaca, N.Y.: Cornell University Press. 